\title{
Rebranding Development Communications in Emergent India
}

\author{
Paula Chakravartty ${ }^{1}$
}

\begin{abstract}
With access to and competence in new ICTs a defining feature of modern citizenship in much of the global South, we need to understand the complex and ambivalent discourse around public-private partnerships, digital inclusion and the very rebranding of development communication in the $21^{\text {st }}$ century. India's prominence in this area is partially explained by the economic and symbolic success of its export-oriented IT industry. The spectacular nature of economic disparities in the world's largest democracy - an emerging market vying for global recognition with some of the most severe rural poverty rates worldwide - has meant that private sector actors are increasingly eager to present themselves as active participants in a new discourse of development. In unequal information societies across the global South like India, a critical analysis of corporate actors in the development arena must take into account the wider field of conflict and struggle over the redistribution of public resources evident in the era of liberalization.
\end{abstract}

Keywords: development communication, India, corporate actors, neoliberalism

\section{The Conscientious Corporation ${ }^{2}$ and India's Unequal Information Economy}

The current Congress Party-led coalition government in India is reeling from a series of corruption scandals, most notably the " $2 \mathrm{G}$ Telecom Scam" involving both Indian corporate powerhouses like Reliance Communication and smaller players like the Unitech Group (partnering with international investors like Norway's Telenor). The scandal became public spectacle when in 2010 a wikileaks-type expose revealed that the telecom Minister had favored specific companies granting undervalued licenses in lieu of a public auction that ultimately cost the government some 1.76 Trillion Rupees (\$39 Billion) in lost revenues (Guha Thakurta and Kaushal 2010). Public outcry about the scale of the corruption scam - which is unprecedented in postcolonial Indian history - has energized opposition parties, emboldened social movements against corruption, led to resignations by implicated bureaucrats and politicians, and spurred ongoing public interest litigation of corporate culpability to the loss of public revenues. It also led to jail sentences for not only the accused Minister in charge (A Raja) along with associated bureaucrats, but also several corporate executives. It could be argued that 
one of the larger fall-outs from this scandal has brought heightened attention to the disproportionate influence of corporate actors in shaping public policy and tarnished the reputations of some of the most iconic capitalist heroes of the liberalization era, including Anil Ambani and Ratan Tata.

How is the $2 \mathrm{G}$ Telecom Scam related to the remaking of development communication in India, one might reasonably ask? In this article, I argue that in many deeply unequal information societies especially in the global South, a critical analysis of corporate actors in the development arena must take into account the wider field of conflict and struggle over the redistribution of public resources evident in the era of liberalization. These issues become especially worthy of critical analysis given the exalted rise of BRICS nations - Brazil, Russia, India, China and South Africa - as exemplary developing economies. These struggles might include claiming access to suddenly valuable resources like the intangible electromagnetic spectrum. Within a mere decade, the Indian telecom market has grown exponentially to become one of the largest and most lucrative in the world. As such, the terms of allocation of this public resource has for the first time in history become a major source of domestic political contention. These struggles also include the relationship between India's well-known information industries and the politically charged question of suddenly valuable acquisition of land, for example as Information Technology (IT) parks across the country are built and expanded on former farmlands. In both cases, powerfully situated corporate actors in the telecom and IT sectors have played a defining role in setting the parameters of economic expansion. It is against this background of conflict and struggle over the privatization of public resources that we must assess efforts by corporate and state actors to rebrand development communication in the $21^{\text {st }}$ century.

In the 2000s, India became a kind of national "best case" role model for informationtechnology infused development, from e-governance to ICT-D. India's importance in this area is partially explained by the symbolic success of its export-oriented Information Technology (IT) industry, often represented as an "engine of growth" for the wider national economy (Chakravartty 2004). The media celebration of the rapid growth associated with the IT industry in info-hub cities like Bangalore, Chennai, Noida (a suburb of New Delhi) and Hyderabad could also be seen as having reinforced the vast disparities between "global" or "shining" India and the growing inequality of everyday life for the vast majority of the nation's citizens (Upadhya and Vasavi 2008). Despite the exuberant discourse of emergent India, even conservative World Bank estimates the percentage of India's 1.15 billion citizens living below the poverty line at 42 percent, while other studies put the figure somewhere between 50 to 77 percent of the overall population. ${ }^{3}$ At both national and regional levels, governments closely associated with neo-liberal economic reform and IT-led development have lost political power and been replaced by political parties promising (although rarely delivering) reform. At the national level, the United Progressive Alliance (UPA) government headed by the Congress Party that has held power since 2004 implemented a series of reforms meant to extend social equity and welfare under the Common Minimum Program, while retaining an overall commitment to liberalization. This same national government is currently caught up in the 2G Telecom Scam, while various regional governments in Andhra Pradesh, Karnataka, Tamil Nadu and West Bengal have paid a political price for "land-grab" scandals often associated with the IT industry. 
How do we evaluate the role of the prominent IT sector in reshaping development communication within this dynamic political field? I will show that we can track clear shifts in the discursive strategy on the part of the IT sector to take on the pressing ethical dilemmas of poverty in the second decade of economic reforms. Interestingly, corporate actors within the Indian IT arena have become the biggest advocates of civil society and "grassroots" technology promotion for the benefit of aam admi (the common man), as opposed to the recognized winners of globalized India - the urban elites. Meanwhile, the state - historically the most prominent institutional actor in the development communication arena - today emphasizes public-private partnerships (PPPs) and incorporates participatory techniques and community/civil society engagement with the objective of promoting "pro-poor pro-market" governance regimes and development projects. These often take as a starting point that all pro-poor solutions to the technical problem poverty alleviation (or closing the digital divide) are amenable to pro-market interventions.

Before going further, it is worth noting that the Indian IT sector is not unique in its targeting of development, and in fact, studies show that corporate philanthropy across the board is on the rise globally, increasingly targeting development programs and often emphasizing ICT-D (Utting 2007). ${ }^{4}$ Moreover, institutional changes within India's development communication field reflect changes at the level of global governance, where we have seen a decade of "the dominance of ICTs as a panacea" for structural problems associated with poverty and inequality (Wilkins \& Chae 2007: 342). The problematic notion of the "global digital divide" and its redress through the World Summit on Information Societies (WSIS) has been the subject of a significant amount of critical research (Pieterse 2000, 2005; Wade 2002; Chakravartty and Sarikakis 2007). This research is relevant for the Indian experience where enthusiasm for ICT-D was widespread in the last decade (Sreekumar 2011), and where corporate actors refashioned themselves as funders and participants in "grassroots" development communication. The following section provides a brief overview of this process and of how it unfolded given the spectacular nature of economic disparities in the world's largest democracy.

\section{Anti-Politics at the Top of the Pyramid}

In The Fortune at the Bottom of the Pyramid: Eradicating Poverty Through Profits, management professor C.K. Prahlad argued: "By stimulating commerce and development at the bottom of the economic pyramid, multi national corporations (MNCs) could radically improve the lives of billions of people and help bring into being a more stable, less dangerous world" (2004: 49). Technology is central to this equation in creating both potential entrepreneurs, but also in fueling the aspirations of potential consumers in rural India, which accounts for much of the empirical evidence for the best selling book. Prahlad and other "management gurus" have had a profound influence in changing the discourse of economic development in India, away from the mandate of state planning, public subsidies and distribution to market-based mechanisms and market-led partnerships.

The role of the capitalist as development visionary is nowhere more apparent than in the IT industry. As observers have noted, capital in India today “...is no longer the privileged bastion of a few mercantile castes" (Damodaran 2009: 312). This widening of the "social base" of a more diversified capitalist class, especially in South India, the 
epicenter of India's IT industry, has created a market populism evident across policy and popular debates. ${ }^{5}$ In the 1990 s, India witnessed the birth of a new transnational capitalist class as familiar icons of Indian modernity, whether they were based in Bangalore like Wipro's Azim Premji or Infosys founder Nandan Nilekani, or if they were NRI (Non Resident Indian) entrepreneurial heroes from Silicon Valley. Following the downturn of the IT industry, this was supplemented by a new discourse of the successful "returning software professional" in cities like Bangalore and Chennai which appeared to prove that Indians did not have to remain abroad to be modern (Pal 2009).

Overall, in India, while private sector philanthropy in absolute terms is relatively low, the influence of the private sector in increasingly shaping development priorities in terms of urban planning, health, education and employment generation has increased substantially in the last decade. Corporate citizenship is certainly the dominant trend in the high-profile IT industry, whether we consider companies like Dell Computers and the HP Foundation, the Microsoft Foundation, the Nasscom Foundation, the Azim Premji Foundation, and hundreds of other cases where firms and their foundations play a driving role in public private partnerships in e-governance, and myriad kiosk and now mobile media-based ICT development projects. Today, at the level of policy, entrepreneurial gurus turned government-appointed cabinet ministers, like Nandan Nilekani, are influential voices in both national and global debates on "rethinking development," particularly in relation to the role of information technologies in spurring (transforming) rapid "leaps" to modernization. ${ }^{6}$ Nilekani's proposition that India can only "reap the demographic dividend" of its large young population by extending the opportunities for education, health, roads, electric power and entrepreneurship to the majority seems innocuous enough (2008). However, his vision of democracy firmly precludes the distributive role of the state, and instead celebrates the autonomous sphere of civil society - the flowering of technically sophisticated civil society organizations working on behalf of majority of Indian citizens holding state institutions accountable - as the only means for the majority of Indians to meet the aspirational goals of modernity. Growing inequality as a result of the economic reforms in the early-1990s is recast in this discourse as an opportunity for rapid inclusion premised on the non-antagonistic relationship between capital and India's often-unruly citizens. This becomes apparent in any cursory overview of the expanding field of ICTD in India in the last decade, where there is broad policy consensus across state and corporate actors around "pro-poor/promarket" objectives (ensuring state accountability and enabling entrepreneurship) and institutional arrangements (public-private partnerships).

What this has meant in practice is the conspicuous absence of public debate about inherently controversial development interventions, reproducing what anthropologist James Ferguson described as the development apparatus operating as an "anti-politics machine". By anti-politics, Ferguson argued that through the institutional practices of development intervention "political questions of land, resources, jobs, or wages" were reconfigured as technical 'problems' responsive purely to "technical development interventions" (1994: 270). These include the rapid privatization of land as in the case of Bhoomi in Karnataka, the commercialization of agriculture as in the case of E-Choupal spanning ten states, and investment in social entrepreneurship as in the large national experiment in establishing 100000 Common Service Centers (CSCs). ${ }^{7}$ Ethnographic field-based studies of several prominent e-governance and tele-center 
projects have demonstrated how varying techniques of de-politicization of the process of development have, if anything, reinforced pre-existing hierarchies in Indian society concentrating power in the hands of the already privileged (Benjamin et. al. 2006; De 2008; Gurumurthy 2009; Pal 2009; Sarkar 2012, Sreekumar 2011).

Here, I am not arguing that this negative outcome is predetermined because of technological intervention (Kuriyan et. al. 2008). Nor would I want to deny, as Kuriyan and Ray (2009) claim based on their study of telecenters in Andhra Pradesh and Kerala, that "public-private tele-centers have created a space for the state to renegotiate its role and image in public service delivery" (7). Clearly, access by marginalized communities to state records in order to ensure the implementation of social programs for social security, food, water and employment are crucial dimensions of state accountability that can be facilitated through digitization schemes, tele-centers and greater access to mobile media. However, these necessarily politicized struggles over the implementation of the Right to Information Act (RTI) are distinct from the dominant policy consensus across corporate and state ICTD actors as they pursue "social entrepreneurship and good governance" (Baviskar 2007; Thomas 2009).

In terms of objectives, there is broad policy consensus that greater access to information reduces both inefficiencies and corruption, exemplified by projects that digitize land records or provide direct information about market prices for agricultural goods. Similarly, there is broad consensus about the compatibility of social development goals of ICTD projects that are meant to simultaneously address rural inequality through "entrepreneurial" success, as is the case with the massive Common Service Center (CSC). Finally, the state has aggressively promoted a PPP model in this area both nationally and regionally, taking as a starting point that private sector participation is key to sustainability and long-term success. Given the growing influence of corporate actors on economic governance in India as discussed in the previous section, it is not surprising that critics have raised concerns about the growing convergence in policy vision in the technology-driven development sector.

While corporate actors have become increasingly active recently in this field, it was initially technologically-savvy bureaucrats, primarily from states in South India (Karnataka, Kerala, Andhra Pradesh and Tamil Nadu), who took the lead in promoting computerization projects meant to make state bureaucracies more accessible to citizens (Pal 2009). Pal has noted that "visionary IT-Friendly" bureaucrats in charge of projects that would become "best practice" exemplars nationally and internationally "were frequently courted by opportunities outside the government," in the private sector, multilateral organizations as well as different levels of government (8). The convergence of these institutional interests in the ICTD field has meant that despite the fact that it is widely understood that most e-governance projects in the "developing world" fail (Heeks 2002, 2008), they continue to be celebrated in media and public policy circles for providing state accountability and fairer market access for the poor.

A case in point is Bhoomi, one of the most praised e-governance projects in India. Bhoomi is a program launched in the fast-growing state of Karnataka, with globally recognized "high-tech" Bangalore as its capital city. Bhoomi is an expansive computerized land-record program involving some 5.7 million land owners across 27000 villages across the state. This project was spearheaded by Rajiv Chalwa, beginning in 2001, a controversial technocrat who would then go on to become the state's e-governance secretary (Pal 
2009). Recognized internationally as a success story, Bhoomi's objectives of good governance are based on holding state corruption in check and are made clear on its website:

Bhoomi (meaning land) is the project of on-line delivery and management of land records in Karnataka. It provides transparency in land records management with better citizen services and takes discretion away from civil servants at operating levels. (http://www.bhoomi.karnataka.gov.in/about.htm)

Lauded by both local and transnational media, Bhoomi's "revolutionary" potential is described in a popular online site, Rediff India Abroad, in the following way:

Bhoomi means that 7 million farmers in Karnataka can get any extract of land records for a flat Rs 15 in the quickest possible time, sans payment of 'speed money'. It is a network of over a thousand offices (including the latest privately run centres), linked via internet to a central depository to which all earlier physical land records have been digitised and transferred. (http://www.rediff.com/ money/2007/apr/10spec1.htm

Media coverage of projects like Bhoomi tends to echo the publicity materials provided by the organizations themselves, more often than not. Media coverage generally affirms that the projects are administered by "forward looking" bureaucrats (Pal 2009), and embody participatory "citizen-centric" programs meant to empower the poor both politically in terms of state accountability and economically in enhancing entrepreneurial as well as consumption capacity. This takes place despite the fact that it is widely acknowledged by the experts themselves that failure rates are high for e-governance projects and tele-centers alike in India and the "developing world" more broadly (Heeks 2002, Toyoma et. al. 2004).

In the case of Bhoomi, an independent report commissioned by the state actually found substantial evidence that small landholders had lost out to large land-holding interests after the digitization of land records (Pal 2009; De 2008). Independent research on Bhoomi's operation in practice by two separate studies found that in certain locales the project tended to reinforce hierarchies of caste and class in land ownership (De 2008) while easing the terms of privatization of rural land for large investors (Benjamin et. al. 2006). Urban studies scholar Solomon Benjamin and his colleagues have gone on to argue that this process facilitated a "land grab" by the powerful IT industry based in Bangalore (Benjamin et. al. 2006; Benjamin et. al. 2008). Instead of whetting the 24hour news channels' voracious appetite for stories about unscrupulous land acquisition - a recurring theme in news coverage in contemporary India - the distribution of the report was actively blocked by the bureaucratic body in charge of the project (Pal 2009).

If Bhoomi is one of India's best-known e-governance success stories, e-Choupal (e-village square) is an internationally recognized success story, this time featuring the social entrepreneurship model of ICTD. Publicity for the project is spelled out on its website featuring visuals that include the familiar motif of smiling farmers surrounding computer screens:

Today 4 million farmers use e-Choupal to advantage - bargaining as virtual buyers' co-operatives, adopting best practices, and matching up to food safety norms. Being linked to futures markets is helping small farmers to better manage risk. e-Choupal has been specially cited in the Government of India's Economic Survey 
of 2006-07, for its transformational impact on rural lives.

http://www.itcportal.com/sustainability/lets-put-india-first/echoupal.aspx

E-Choupal is a private sector initiative by ITC with diversified interests ranging from cigarettes, to hotels to agri-business, ranked as India's tenth most valuable transnational brand with a turnover of over US \$5 billion (Dangi and Singh 2010). According to C.K. Prahlad, where e-Choupal featured prominently as a best practice model of social entrepreneurism, ITC's success in creating a "pro-poor/pro-market" formula that works is based on the company's commitment to the "social agenda" and its dedication to "nation building" (2006: 325-329). The scale of the project, deployed across 10 states and serving some 40000 villages, the largest operational ITCD project, is in itself impressive. While there is evidence that the project has increased rural agricultural incomes by introducing "efficiency improvements in the procurement chain," the distributional impact of these benefits has been uneven, and, like Bhoomi, data suggests that it might in fact reinforce inequalities for the majority of small land-holders (Dangi and Singh 2010). Moreover, critics have pointed out that the initiative seeks to become the "Walmart of rural India" (Gurumurthy 2009), with essentially "monopolitistic control over the entire local agriculture ecology by a transnational corporation through the use of a captive ICT infrastructure with minimal regulation and competition" (Dangi and Singh 2010: 182). Based on a business model providing connectivity and services to a closed network of farmers through an entrepreneur whose role, interestingly, is projected by ITC as a "public office" (Prahalad 2006: 179), e-Choupal exemplifies the win-win logic of this new development discourse (Gurumurthy 2009).

This brief and critical overview of projects that are both locally and internationally recognized for their "empowerment" of poor farmers in India is meant to draw attention to the limits of the "anti-politics" turn in information-based development in India and beyond. Empirical research on ICTD in India is extensive, and the limits of much of the policy-driven analysis on development outcomes has already been spelled out by a range of critics, from scholars (Pal 2009; Schwittay 2008; Sreekumar 2007, 2011; Thomas 2008; Sarkar 2012) to NGO-based activists (Gurumurthy 2009, Benjamin et. al. 2006), and even by collaborations between academics and researchers based in corporate think-tanks (Burrell and Toyoma 2009; Kuriyan, Ray and Toyoma 2008).

My purpose in drawing attention to these particular exemplary ICTD projects, celebrated by a variety of national and international foundations, is to show the obvious contradictions between the "pro-poor/pro-market" framework that forms the normative basis for the vast majority initiatives in India. These modernization schemes promised to democratize the benefits of India's skewed information society. And within a decade, "pockets" of rural India became a "Living Lab" for public-private partnership based delivery of information technology, promising nothing short of social transformation (Schwittay 2008).

To give some sense of the scale of this sector, one independent report estimated in 2007 that there were between 12000 and 13000 tele-centers or cyber-kiosks operating in the country, with approximately 50 percent as state operated or public-private partnerships, and the rest as private for-profit initiatives in areas like e-agriculture (GISW, 2007: 158). The Government of India is presently spending INR 230 Billion (or between two to three percent of its overall budget) on its National E-Governance Plan. The center- 
piece of the scaled up project of national e-governance, announced in 2006, was a plan to establish 100000 Common Service Centers (CSC) across India's 600000 villages. The objective was to establish a "multistakeholder" program that allows "the common man" greater access to government services and the opportunity for "rural entrepreneurship". Although the Department of Information Technology claims that some 97,450 of these CSCs are operational as of 2011, emphasizing the "success stories" of hundreds of "Village Level Entrepreneurs" who provide the "vital link" to remote rural communities by literally embodying the bridge to the so-called "digital divide," ongoing critical exploration of these projects on the ground are likely going to tell very different stories. ${ }^{8}$

\section{Conclusions}

In the last decade, India became a thriving site for local and regional case studies of a rebranded exercise in development communication. The design, implementation and evaluation of what are surely dizzying numbers of localized development experiments have created an army of experts in e-governance and grassroots digital inclusion efforts. These experts are tirelessly collecting survey and ethnographic data, presenting powerpoints and meeting in what has become an institutionalized succession of workshops, conferences and symposiums where the technologically enhanced rights of the newly empowered citizen are mapped, charted and recalibrated for the next cycle of projects in India and well beyond. Most of these "in-house" studies focusing on developmental outcome tend to assume that indicators measuring economic efficiency translate directly into economic development across entire communities. What a series of ethnographic critical research in this area has established is that access to ICTD rarely undoes structural inequalities in terms of class, gender biases or caste discrimination, and in fact often reinforces those very inequalities in practice (Benjamin et. al. 2008, 2006; Sarkar 2012, Sreekumar 2011).

This model of rebranded development communication is a subject of concern not just within India, but also in the rest of South Asia, Southeast Asia, Africa and the Arab World. In Africa in particular, the Indian "footprint" is quickly growing as telecom, software and IT companies begin to recognize the market potential of the development industry. To this point, Sunil Bharti Mittal, chairman of one of India's leading telecom giants Airtel, highlights India's shared history with Africa based on its colonial and post-colonial struggle for development and dignity. It is apparently a shared history of anti-colonial struggle and the non-alignment movement that gives India a comparative advantage "culturally" in accessing the African market. Airtel recently purchased 15 telecom companies in sub-Saharan Africa for an estimated value of over \$10 Billion, and Mittal in his essay entitled "The Coming of a New Dawn" perfectly captures the "pro-poor" pro-market vision of ICTD discussed above. ${ }^{9}$

In this article, I have situated the rise of ICTD as a seemingly successful experiment in rebranding development communications in India over the last 15 years. An earlier stage of e-governance projects were based on digitizing and modernizing government bureaucracies and record keeping, essentially the aim in these projects was to make government administration more "efficient and transparent". India's success as an ICTmodernization leader, however, is based on a second wave of e-governance projects that emerge in the mid-1990s to the present, with participatory "citizen-centric" programs 
meant to empower the poor both politically in terms of government accountability and economically in enhancing entrepreneurial capacity (Madon 2004). Although it is widely recognized that the vast majority of e-governance projects in the "developing world" fail (Heeks, 2005),${ }^{10}$ the success of some of India's best known projects have received international awards for best practice and have become new models empowerment and good governance around the world (Sreekumar 2007, 2011, Thomas 2010 ).

Drawing on critical overviews of two of the best-known ICTD projects in India, I have outlined general trends that are apparent across a much wider swathe of ICTD projects both in India today. The contradictions of the pro-poor/pro-market logic that informs projects like Bhoomi, in Karnataka and e-Choupal across 10 states in the country, are instructive of the limits of the rebranded development communication vision. Under these new terms, the poor have been reframed in development communication discourse as empowered only in relation to holding state institutions accountable, demonstrating their agency only as aspiring consumers and potential entrepreneurs. This is representative of what has been described as processes of "expert closure" around the terms of debate in participatory development projects, where more fundamental questions around inequality are "off-limits" as argued by David Mosse (2005), Tania Murray Li (2009), among other critical researchers of development.

This new framing of the poor is distinct from previous discourses of development in the longer history of state-led post-colonial development in India (Chakravartty 2007, 2010). In this article, I emphasized the newly prominent role of private sector actors in shifting the discourse on economic development and identifying solutions for poverty, both rural and urban. While private sector philanthropy in absolute terms is relatively low in India, the influence of the private sector in increasingly shaping development priorities in terms of urban planning, health, education and employment generation has increased substantially in the last decade. Corporate citizenship is certainly the dominant trend in the high-profile IT industry, whether we consider companies like Dell Computers and the HP Foundation, the Microsoft Foundation, the Nasscom Foundation, the Azim Premji Foundation, and hundreds of others where firms and their foundations play a driving role in public private partnerships in e-governance, and myriad kiosk and now mobile media-based ICT development projects.

I have argued that the re-vamped role of the private sector across India's deeply unequal information societies has to be assessed in terms of what have been highly charged political struggles over the liberalization and privatization of public resources - whether intangible spectrum allocation, or the violence over land acquisition. The transnational IT industry elite in India who became iconic representatives of a new Indian capitalism, had a "disproportionate impact on public policy" both though national business associations and transnational business networks (Upadhya 2004). As industry insiders themselves point out, NASSCOM (the national IT trade association) and transnational IT industry in India have been extremely successful in "wresting most concessions they want from government" including stronger IPR regimes and favorable tax and labor and infrastructure policies, while presenting themselves as vocal critics of government-led development and institutionally autonomous from state power (Atheye and Chaturvedi 2006: 25).

The role of the IT industry in promoting a very specific agenda for development in India reflects neoliberal shifts in governance, where national states are learning from 
and behaving more like transnational corporations, while transnational corporations and national corporate stars alike invest significant sums on public relations efforts to prove that they are in fact, good citizens. The resurgence of development communications in the $21^{\text {st }}$ century is clearly more sophisticated than simply winning the hearts and minds of the "Third World masses" by exposing "pre-modern" subjects to mass media. Contemporary discussions about the virtues of the global information society are based on claims about how access to mobile media, the Internet, tele-centers, and today social media, enshrine a set of rights vested with the magical potential to flatten institutional hierarchies and thereby transform the lives of impoverished individuals and their communities in villages, small towns and urban peripheries across the North and South.

There are clear differences between the geopolitically charged experiments in modernization from above (and by largely foreign actors) and current iterations emphasizing the organic synergy between corporate and state partnerships and local civil society and individual empowerment. Today's politically neutral tone of modern development and new participatory approaches help to depoliticize what are deeply contested transformations of public resources across India's fractured economy and society. In the end, the rebranding of development communication in India holds bigger lessons for how we might want to critically study the role of technology in shaping development. As we have seen, behind the pragmatic and politically neutral tone of the now more nuanced discourse of development, we see an astonishing acceleration both in the scale of development projects based on information and communication technologies and in its symbolic significance in promising a painless transition to modernity.

\section{Notes}

1. Paula Chakravartty is Associate Professor, Department of Communication, UMass Amherst, US. E-mail: pchakrav@comm.umass.edu

2. I am using a term that is developed by Christina Gartsen and Tor Hernes (2009) in distinguishing a new turn in how "corporate actors position themselves in society and rework organizational boundaries (197)." I will discuss this further in the article.

3. http://www.im4change.org/articles.php?articleId=40\&pgno=2

4. Lahiri and Pal (2009) have argued that increasingly "a sizeable number of companies that do not make their money from technology are nonetheless including what one may consider 'ICTD' projects in their CSR funding profiles." These include Citigroup, ExxonMobil and Walmart.

5. It is important to point out that the issue of greater diversity across India's liberalized private sector is a source of controversy, with empirical studies showing the reverse to be true for example in Bangalore's IT industry (Upadhya and Vasavi, 2006). And Harish Damodaran (2009), who makes the case for greater diversity in caste backgrounds of "India's new capitalists" finds that "The group that has... been bypassed in this churning of capital and widening of its social base are the Dalits" (315).

6. In 2009, Nilekani became a cabinet member in the ruling UPA government as Chair of the Unique Identification Authority of India, the controversial national program to issue identity cards based on biometric data. Advocates claim the program will allow the poor better access to services while critics worry about civil rights and greater surveillance of already marginalized communities.

7. Benjamin et. al. (2006), De (2008) and Thomas (2009) all discuss the case of Bhoomi. E-Choupal is discussed in Gurumurty (2009) and Dangi and Singh (2010). My analysis of the CSC project is based on my own on-going field-work in Delhi, Andhra Pradesh and West Bengal since 2008.

8. Current figures given by the DoIT can be found at: http://www.mit.gov.in/content/common-servicescenters. Also, on the same page, is a link to a report on "CSC Success Stories" highlighting individual experiences of Village Level Entrepreneurs.

9. http://2billiondreams.in/index.php?param=chapterdetails/12

10. Richard Heeks(2010), one of the most prominent scholars and advocates in the field of ICT-D has more recently argued that despite gains in terms of development through ICTs: 
"ICTs in low-income countries and communities may represent an excess of cost over economic benefit... they may not sustain... and they may fail to enhance capabilities."

While Heeks calls for the need for better empirical studies of impact, my point here has to do with the somewhat puzzling implicit enthusiasm for these projects in India in the last decade.

\section{References}

Athreye, S. and Chaturvedi, S. (2007) "Industry Associations and technology-based growth in India," European Journal of Development Research. Retrieved March 15 ${ }^{\text {th }}$, 2009: http://www.ilo.int/public/english/ bureau/inst/papers/confrnce/research/sumapaper.pdf

Baviskar, A. (2007) "Is Knowledge Power? The Right to Information Campaign in India," London: Institute of Development Studies Working Paper.

Benjamin, S., Bhuvaneshwar, R. and Rajan, R. (2008) "Fractured Terrain, Spaces Left Over or Contested: A Closer Look at the IT-dominated Territories in South and East Bangalore,” in D. Mahadevia (Ed.) Inside Transforming Urban Asia: Processes, Policies and Public Actions. New Delhi: Concept Publishing: 239-285.

Benjamin, S., Bhuvaneshwari, R. and Rajan, P. (2006) 'E-Titling' of an 'Anti-Politics Machine' to Globalize Bangalore. International Conference on Enhancing Land Registration Cadastre for Economic Growth in India. New Delhi: Center for Science, Development and Media Studies.

Chakavartty, P. (2007) "Governance Without Politics: Civil Society, Development and the Postcolonial State" International Journal of Communication 1: 1-22.

Chakravartty, P. (2001) "Flexible Citizens and the Internet: The Global Politics of Local High-Tech Development in India," Emergences: Journal for the Study of Media and Composite Cultures, 11 (1): 69-88.

Chakravartty, P. and Zhao, Y. (eds.) (2008) Political Economy of Global Communication: Towards a Transcultural Perspective. Boulder: Rowman \& Littlefield

Chakravartty, P. and Sarikakis, K. (2006) Globalization, Communication and Media Policy: A Critical Perspective. Edinburgh: Edinburgh University Press

Dangi, N. and Singh, H. (2010) "e-Chopal: Hope or Hype?" American Journal of Economics and Business Administration. 2 (2): 179-184.

De, R. (2008) "Control, De-Polititicization and the eState," Lecture Notes in Computer Science (LNCS) 5184: 61-74.

Escobar, A. (1994) Encountering Development: The Making and Unmaking of the Third World. Princeton: Princeton University Press.

Ferguson, J. (2006) Global Shadows: Africa in the Neoliberal World Order. Durham: Duke University Press. Ferguson, J. (1994) The anti-politics machine: development, depoliticization and bureaucratic power in Lesotho. Minneapolis: University of Minnesota Press.

Fuller, C.J. and Narasimhan, H. (2007) "Information Technology Professionals and the New Rich Middle Class in Chennai (Madras)" Modern Asian Studies, 41 (1): 121-150.

Gartsen, C. and Hernes, T. (2009) "Beyond CSR: Dilemmas and Paradoxes of Ethnical Conduct in Transnational Organizations," in K. E. Browne and B. L. Milgram (eds.) Economics and Morality: Anthropological Approaches, Plymoth, UK: AltaMira Press:189-210.

Guha Thakurta, P. and A. Kaushal (2010) "Underbelly of the great Indian Telecom Revolution” Economic and Political Weekly, XLV (49): 59-55.

Gupta, A. (1998) Postcolonial Developments: Agriculture in the Making of Modern India. Durham: Duke University Press.

Gurumurthy, A. (2009) "Social Enterprises to Mobiles: The Curious Case of Propped-Up ICTD Theory" Berkman Cetner for Internet and Society, Harvard. Retrieved January 18 ${ }^{\text {th }}$, 2010: http://publius.cc/ social_enterprise_mobiles_\%E2\%80\%93_curious_case_propped_ictd_theory/091709

Heeks, R. (2008) "ICT4D2.0: The Next Phase of Applying ICT for International Development," Computer. $41(6): 26-33$.

Heeks, R. (2002) "Information Systems and Developing Countries: Failures, Successess and Local Improvisations," The Information Society, 18 (2): 101-112.

Kuriyan, R. and Ray, I. (2009) "E for Express: "Seeing" the Indian State through ICTD” IEEE/ACM Proceedings, Information and Communication Technology and Development, 2009. Retrieved January $15^{\text {th }}: 2010$ : http://docs.google.com/viewer?a=v\&q=cache:n3TRzvxP59IJ:tier.cs.berkeley.edu/tierwiki/media/a/a9/ ReneeKuriyan_IshaRay_ICTD2009.pdf+E+for+Express:+\%E2\%80\%9CSeeing $\%$ E2\%80\%9D+the+Indian + State + through + ICTD $\%$ E2\%80\%9D\&hl=en\&gl=us\&pid=bl\&srcid=ADGEESgeJBc_7X1ZFQZ4gelTc7TR vqjwb4G_wZhHWlvItoj9V99_b91VEBnrf26_yPNQOak5xuqjzNmAWFOHElkWJCL1diLGNQ6X2582rjCpXIFdOuwpiw5kNSOeMvjuvSIH5xhb1FXD\&sig=AHIEtbSdzuutfSd61mjCDu2yoYymMY1uMg 
Kuriyan, R, Ray, I. and Toyoma, K. (2008) "Information and Communication Technologies for Development: The Bottom of the Pyramid Model in Practice," Information Society. 24: 1-12.

Mosse, D. (2005) Cultivating Development: An Ethnography of Aid Policy in Practice. New York: Pluto Press.

Microsoft Corporation (July 22, 2008) "Microsoft Strives to Bring Relevant, Affordable and Accessible Technologies to the World's Rural Underserved Populations,” Retrieved November 14 ${ }^{\text {th }}$, 2009: http:// www.gkpeventsonthefuture.org/

Murray Li, T. (2007) The Will to Improve: Governmentality, Development and the Practice of Politics. Durham: Duke University Press.

Nilekani, N. (2008) Imagining India: Ideas for the New Century. Delhi: Penguin.

Pieterse, J.N. (2005) "Digital Capitalism and Development: The Unbearable Lightness of ICT4D," in, G. Lovink and S. Zehle, (eds) Incommunicado Reader. Amsterdam: Institute of Network Cultures: 11-29

Pieterse, N. (2000). 'Trends in Development Theory'. In R. Palan (ed.) Global Political Economy: Contemporary Theories. London and New York: Routledge: 197-214

Sarkar, S. "Passionate Producers: Corporate Interventions in Expanding the Promise of the Information Society" International Journal of Communication (Forthcoming)

Schwittay, A. (2008) “'A Living Lab': Corporate Delivery of ICTs in Rural India” Science, Technology \& Society. 13 (2): 175-209.

Sreekumar, TT. (2011) ICTs and Development in India: Perspectives on the Rural Network Society. New York: Anthem Press.

Sreekumar, T.T (2007) "Cyber-Kiosks and the Dilemmas of Social Inclusion in Rural India", Media, Culture and Society. 29: 869-887.

Sinha, A. (2005) "Understanding the Rise and Transformation of Business Collective Action in India," Business and Politics. 7 (2): 1-35.

Thomas, P. (2009) "Bhoomi, Gyan Ganga, e-governance and the right to information: ICTs and development in India," Telematics and Informatics. 26 (1): 20-31.

Toyoma, K. et. al. (2004) "Rural Kiosks in India," ResearchMicrosoft: Retrieved June 9 ${ }^{\text {th }}$, 2008: http://research. microsoft.com/apps/pubs/default.aspx?id=70150

Upadhya, C. (2004) "A New Transnational Capitalist Class? Capital Flows, Business Networks and Entrepreneurs in the Indian Software Industry." Economic and Political Weekly. November $27^{\text {th }}: 5141-5151$.

Upadhya, C. and A.R. Vasavi (2008) "Outposts of the Global Information Economy" in C. Upadhya and A.R. Vasavi (eds.) In an Outpost of the Global Economy: Work and Workers in India's information Technology Industry. New Delhi: Routledge: 9-49.

Utting, P. (2007) “CSR and Equality” Third World Quarterly. 28 (4): 697-712.

Wade, R.H. (2002) "Bridging the digital Divide: New Route to Development or New Form of Dependency?" Global Governance. 8(4): 53-8 